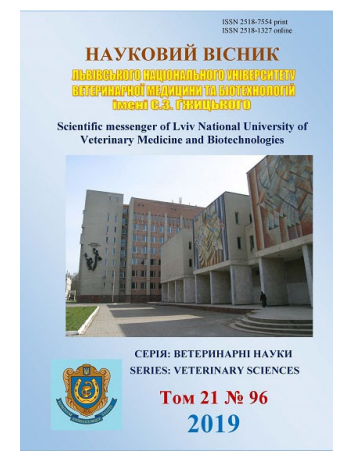

\author{
Науковий вісник Львівського національного університету \\ ветеринарної медицини та біотехнологій імені С.З. Гжицького. \\ Серія: Ветеринарні науки
}
Scientific Messenger of Lviv National University of Veterinary Medicine and Biotechnologies. Series: Veterinary sciences

ISSN 2518-7554 print ISSN 2518-1327 online doi: $10.32718 /$ nvlvet9633

http://nvlvet.com.ua

UDC 619:616.33-002:636.1

\title{
Pathomorphological study on gastric ulceration in horses
}

\author{
O. Stefanyk, L. Slivinska
}

Stepan Gzhytskyi National University of Veterinary Medicine and Biotechnologies Lviv, Ukraine

Article info

Received 12.11.2019

Received in revised form 16.12 .2019

Accepted 17.12.2019

Stepan Gzhytskyi National University of Veterinary Medicine and Biotechnologies Lviv, Pekarska Str., 50, Lviv, 79010, Ukraine. Tel.: +38-063-649-99-20 E-mail: ostapstefanyk@gmail.com
Stefanyk, O., \& Slivinska, L. (2019). Pathomorphological study on gastric ulceration in horses. Scientific Messenger of Lviv National University of Veterinary Medicine and Biotechnologies. Series: Veterinary sciences, 21(96), 192-197. doi: 10.32718/nvlvet9633

Equine gastric ulcer syndrome (EGUS) is characterized by ulceration in the terminal esophagus, proximal (squamous) stomach, distal (glandular) stomach, and proximal duodenum. It is a common disease in all breeds and ages of horses and foals. Risk factors for EGUS include stress, transport highenergy feed confinement in stalls, intermittent feed, and intense exercise and racing. Horses are very sensitive to any environmental change, which is cause of high prevalence of gastric ulcers especially in racing horses. Taking into consideration of high prevalence of EGUS, our research work was based on pathomorfological and gross evaluation of gastric mucosa in different breeds of horses. Assessment of the severity of lesions is most commonly achieved by assigning a grade that describes the mucosal appearance at different anatomic sites. A variety of different systems have been published for the horses. 10 stomachs were removed from a mixed population post mortem. In our study pathological classification of lesion type was evaluated by two different scoring system, with scales ranging from 0-4. Samples from areas with lesion were taken for histopathology evaluation. EGUS was confirmed on stomachs of six horses. Lesions with different score mostly localized on squamous region near margo plicatus. Changes on squamous mucosa was confirmed on stomach of four horses as well as glandular region two horses. According to score systems mentioned in publication changes on gastric mucosa was measured up 1, 2, 3 score and were characterized as hyperceratosis, erosions and deeper lesion involving the mucosa, extending to the submucosa layer and hyperemia of glandular mucosa. The results of pathomorphological examination of the condition of the wall of the gastric mucosa and histological changes, the effectiveness of the submitted classification systems was established.

Key words: Egus, stomach, ulcer, squamous mucosa, glandular mucosa, hyperkeratosis, erosion.

\section{Патоморфологічна оцінка стінки шлунка за синдрому виразки у коней}

\author{
О.В. Стефаник, Л.Г. Слівінська
}

Львівський національний університет ветеринарної медиџини та біотехнологій імені С.З. Гжицького, м. Львів, Украӥна

Синдром виразки шллнка коней "Equine gastric ulcer syndrome" входить у групу захворювань, які включають: ерозї та виразки слизових оболонок шлунка та проксимального відділу дванадиятипалої кишки. Основною причиною синдрому в усіх коней є порушення балансу бар'єрної функції шлунка та факторів її агресії. Порушення балансу виникає при не правильній годівлі, стресах, довготривалому задаванню нестероїдних протизапальних препаратів (НПЗП), транспортуванні коней. Вони є дуже чутливими до таких змін, тому наявність виразок є поширеною проблемою особливо у верхових порід коней. Беручи до уваги поширеність даної патології, нами було проведено патоморфологічну оиінку стану слизових оболонок стінки илунка завдяки методиці із використанням різних ступеневих систем класифікації. У статті подано макроскопічну та мікроскопічну оцінку стану слизових оболонок стінки шлунка десяти коней після забою. Для патоморфологічного дослідження відбір зразків проводився з місиь ураження стінок, що фіксувались в 10\% розчині формаліну. За результатами проведених досліджень синдром виразки шлунка був встановлений у шести коней. Зміни різного ступеня та характеру локалізувались на незалозистій слизовій оболониі, поряд з межею тагgо plicatus. У двох коней було виявлено зміни на слизовій оболонці залозистого відділу шлунка. Згідно поданих систем класифікації на 
стінках незалозистого відділу шлунка нами виявлені зміни 1, 2, 3 ступенів, щуо характеризувались гіперкератозом, ерозіями та проникаючими виразками із пошкодженням м'язового шару. Зміни 1 та 2 ступенів - гіперемія слизової оболонки виявлена на стінках фундального відділу шлунка. За результатами проведення патоморфологічного доіслдіження стану стінки слизової оболонки шлунка та гістологічних змін встановлено ефективність поданих систем класифікації.

Ключові слова: Egus, Eggd, Egsd, илунок, виразка, незалозистий відділ, фундальний відділ, гіперкератоз, дифузні ерозії, гіперемія.

\section{Вступ}

Синдром виразки шлунка Equine Gastric Ulcer Syndrome "Egus" є поширеним захворюванням особливо в коней з активним тренінгом та може виникати як і в лошат так і в дорослих коней.

Останнім часом спостерігається позитивна динаміка серед поширеності виразок слизових оболонок шлунка у верхових порід коней. Наукові дані вказують на поширеність даної патології коней в період посиленого тренінгу і сезону змагань $\geq 80 \%$ (Johnson et al., 1994). Виразки зазвичай локалізуються на незалозистій слизовій та в ділянці margo plicatus. Також вони часто уражають залозисту слизову та пілоричний відділ шлунка. За результатами досліджень (Ward et al., 2015), на англійській чистокровній породі коней у Великій Британії поширеність виразок у ділянці залозистої слизової оболонки встановлено (8\%-63\%), на фундальній та пілоричній ділянці (40\%-90\%) (Buchanan \& Andrews, 2003; Camacho-Luna et al., 2017). Основною причиною синдрому в усіх коней є порушення балансу бар'єрної функції шлунка та факторів iii агресії. 3 перших факторів захисту виділяють бікарбонат, слиз та простагландин Е2, котрий забезпечує секрецію слизисто-бікарбонатного шару, зменшення його синтезу супроводжується пригніченням факторів захисту шлунка. До агресивного середовища відносять хлоридну кислоту (HCL), жовчні кислоти та пепсин, що синтезуються залозами шлунка. Порушення балансу виникає при не правильній годівлі, стресах, довготривалих задаваннях НПЗП, транспортуванні, що надалі у процесі патогенезу виразки викликає зміни слизових оболонок шлунка під впливом агресивного середовища шлунка (Bell et al., 2007).

Анатомічно, незалозиста слизова оболонка не має бар'єрної функції на відміну від залозистої, постійне подразнення іiі стінки викликає десквамацію поверхневого епітелію, що призводить до виникнення ерозій та виразки. Ступінь ураження стінки залежить від тривалості іiі подразнення хлоридною кислотою (Bell et al., 2007).

У зв'язку з різними факторами виникнення, перебігу і типу ураження прийнято використовувати загальний термін синдром виразки шлунка Equine gastric ulcer syndrome "EGUS" для опису цієї хвороби. В залежності від місця локалізації класифікують синдром виразки незалозистої Equine gastric squamous disease "EGSD" і залозистої слизової оболонок Equine gastric glandular disease "EGGD".

Клінічні ознаки захворювання не є специфічними i можуть проявлятись порушенням апетиту, втратою ваги, зниженням працездатності, слабкими ознаками колік. Ретроспективні дослідження також вказують на відсутність змін морфологічних та біохімічних показників крові за виразки шлунка, тому основним методом діагностики є гастродуоденоскопія (Sykes et al., 2015). Для оцінки ступеня ураження слизових оболонок існують різні системи класифікації, що грунтуються на визначенні локалізації, кількості та глибини проникнення (MacAllister et al., 1997; Andrews et al., 1999; Martineau et al., 2009; Sykes et al., 2015; Stefanyk \& Slivinska, 2018). Такі методики є ефективними для моніторингу перебігу хвороби та його лікувального ефекту. Проте аналіз літературних джерел вказує на обмеження ендоскопічних даних та кореляції їх 3 гістологічною картиною виразки шлунка. Такі порівняльні дані $є$ більш інформативними для підтвердження діагнозу EGUS при різному патогенезі та перебігу виразки.

На сьогодні $є$ наукові праці (Murray et al., 2001; Andrews et al., 2002) де наявні гістологічні дані зразків відібраних 3 місць ульцерації, що були викликані експериментальним шляхом в чистокровних порід коней. Водночас відсутні дослідження зокрема (патоморфологічна діагностика) за EGUS у різних порід коней. А більш детальне варіативне дослідження слизової оболонки шлунку при різних ступенях ульцерації, дасть змогу краще зрозуміти патогенез хвороби та покращити профілактичні та лікувальні заходи в подальшому (Martineau et al., 2009).

Аналізуючи літературні джерела хочемо зазначити, що EGUS є недостатньо вивчений в Україні і потребує подальшого дослідження щодо вдосконалення методів діагностики 3 метою ефективного лікування та профілактики.

Метою роботи було проведення патоморфологічного дослідження стану стінки шлунку у коней і на основі гістологічних змін встановити ефективність та практичність поданих систем класифікації.

\section{Матеріал і методи досліджень}

Шлунки чотирьох коней були відібрані в прозекторії кафедри нормальної та патологічної морфології і судової ветеринарії Львівського національного університету ветеринарної медицини та біотехнологій імені С.3. Гжицького, а також шести коней - на забійному пункті м. Великі Мости в продовж 2019 року. Коні, які піддавались забою були різної породи, віку та статі (табл. 1).

Дослідження проводились на кафедрі нормальної та патологічної морфології i судової ветеринарії Львівського національного університету ветеринарної медицини та біотехнологій імені С.3. Гжицького. Проби відбирали безпосередньо після загибелі тварин. 


\section{Таблиця 1}

Порода, вік та стать коней

\begin{tabular}{lcl}
\hline \multicolumn{1}{c}{ Порода } & Вік & Стать \\
\hline Гуцульська & 7 & Кобила \\
Торійська & 13 & Кобила \\
Англійська Чистокровна & 8 & Мерин \\
Гуцульська & 14 & Кобила \\
Українська верхова & 8 & Кобила \\
Торійська & 6 & Мерин \\
Поні & 19 & Кобила \\
Поні & 22 & Кобила \\
Українська верхова & 7 & Мерин \\
Українська верхова & 13 & Кобила \\
\hline
\end{tabular}

Поетапна препарація шлунка проводилась зі сторони стравоходу перед краніальним сфінктером та входу в пілоричний відділ шлунка з частиною проксимальної дванадцятипалої кишки. Шлунок відкривали повздовжнім розрізом від стравоходу по великій кривизні шлунка. Зразки $з$ місць ульцерації розміром $2 \times 2$ см. відбирались скальпелем захоплюючи серозний шар та поверхневий епітелій стінки шлунка, що фіксувались в $10 \%$ розчині формаліну. Гістозрізи виготовляли товщиною 4-5 мкм із парафінових блоків, отримували на мікротомі MC-2 та фарбували гематоксиліном еозином за методом МакМануса та Стідмена, метиловим зеленим та піроніном G за Браше, суданом-III. Отримані препарати проглядали 3 використанням світлового мікроскопа Leica Dm-2500 (Switzerland). Фотофіксацію зображення здійснювали 3 використанням цифрової камери Leica DFC450C та програмного забезпечення Leica Application Suite Version 4.4.

\section{Класифікаиія.}

Для оцінки виявлених змін на слизових оболонках використовували дві ступеневі системи класифікації для макроскопічної (табл. 2). (Macallister et al., 1997) та гістологічної оцінки відібраних зразків (табл. 3). "Histopathology (HSS) scoring system" (Andrews et al., 2002).

\section{Таблиця 2}

Ступенева система класифікації виразок незалозистої слизової оболонки шлунка

Grading system for equine squamous gastric disease

\begin{tabular}{|c|c|}
\hline Ступінь 0 & $\begin{array}{l}\text { Епітелій незмінений, слизова без гіпе- } \\
\text { ремії, без гіперкератозу }\end{array}$ \\
\hline Ступінь 1 & $\begin{array}{l}\text { Епітелій незмінений, наявні ділянки } \\
\text { гіперемії або гіперкератозу }\end{array}$ \\
\hline Ступінь 2 & $\begin{array}{c}\text { Наявні дрібні маленькі або мультифо- } \\
\text { кальні ураження }\end{array}$ \\
\hline Ступінь 3 & $\begin{array}{c}\text { Наявні великі, поодинокі чи мультифо- } \\
\text { кальні ураження або великі ділянки } \\
\text { поверхневих уражень }\end{array}$ \\
\hline Ступінь 4 & Наявні великі глибокі виразки \\
\hline
\end{tabular}

В залежності від місця локалізації уражень, класифікували згідно анатомічних ділянок на кардіальну, фундальну, пілоричну частини шлунка. Для більш детального опису анатомічних ділянок шлунка засто- совували терміни: велика, мала кривизна шлунка, margo plicatus. За типом ураження виразки класифікували на фокальні, мультифокальні та дифузні.

\section{Таблиця 3}

Ступенева система оцінки гісто-патологічних зразків Histopathology (HSS) scoring system

\begin{tabular}{cc}
\hline Ступінь 0 & $\begin{array}{c}\text { Епітелій не ушкоджений (можуть бути } \\
\text { присутні незначні нашарування, слабкі } \\
\text { ознаки гіперкератозу) }\end{array}$ \\
Ступінь 1 & $\begin{array}{c}\text { Поверхневі ураження слизової оболонки } \\
\text { (ерозії) }\end{array}$ \\
Ступінь 2 & Глибші ураження підслизового та \\
слизового шарів \\
Ступінь 3 & Глибокі виразки з ураженнями підслизо- \\
& вого та слизового шарів з проникненням у \\
власне м'язовий шар
\end{tabular}

\section{Результати та їх обговорення}

Класифікація уражень в ділянщі незалозистої слизової оболонки.

У ході патоморфологічного дослідження стінки шлунка коней виявлено ділянки гіперкератозу слизової оболонки у п'яти особин. Макроскопічно характерним було незначне сухувате нашарування з жовтуватим відтінком на стінках незалозистої слизової оболонки шлунка в ділянці великої кривизни поряд 3 межою margo plicatus (рис. 1a). Гістологічно ідентифікували значне нашарування, еозинофільного зроговілого епітелію на слизовій оболонці, що зумовило значне його потовщення i вказувало на розвиток гіперкератозу (рис. 1в). Відомо, що гіперкератоз $\epsilon$ захисною реакцією яка очевидно була викликана тривалою дією екзогенних чинників та гіповітамінозом А. Капілярна активність та збільшення кількості лімфоцитів в межах власної пластинки lamina propria також були присутні у більшості випадків.

Дифузні ерозії виявлені на двох відібраних шлунках локалізувались в межах margo plicatus та малої кривизни шлунка, з властивими дрібними та мультифокальними ураженнями. Гістологічно виявляли кратероподібні виїмки у стінках слизової оболонки (рис. 2 б). Значне пошкодження епітеліального шару слизової оболонки та підслизового шару, без проникнення у власне м'язовий шар, що супроводжувалось капілярною реакцією та дистрофічно-некротичними змінами епітеліальних клітин незалозистої слизової оболонки, помірною інфільтрацією клітинними елементами: лімфоцитами та нейтрофілами у власній пластинці lamina propria.

Макроскопічно типові локальні виразки виявлені у двох шлунках. Вони характеризувались глибоким пошкодженням слизової оболонки (рис. 3 a, б), завширшки від 3 до 4,5 см, що локалізувались у ділянках кардіального сфінктера та великої кривизни шлунка. За гістологічного дослідження в стінці шлунка хворих коней виявили ділянки значного руйнування слизового та підслизового шарів, 3 подальшим проникненням у власне м'язовий шар. Це супровод- 
жується відшаруванням епітелію слизової оболонки, реакцією в підслизовій основі стінки шлунка, яка супроводжується проліферацією макрофагів, гістіо- цитів та виходом плазми у міжклітинний простір (рис. 3 в).

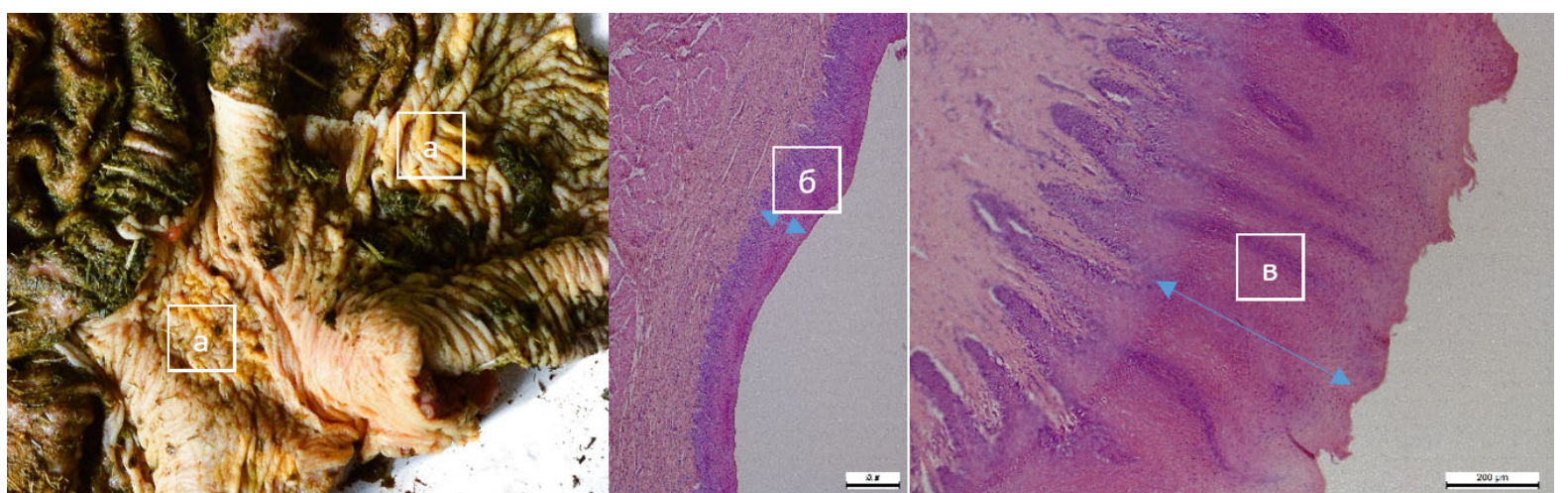

Рис. 1. (а) Гіперкератоз в ділянках великої кривизни шлунка та поряд з межою margo plicatus. (б) багатошаровий зроговілий епітелій в нормі. Bar $=50 \mu \mathrm{m}$. (в) Нашарування зроговілого епітелію - ознаки гіперкератозу.

Bar $=200 \mu \mathrm{m}$

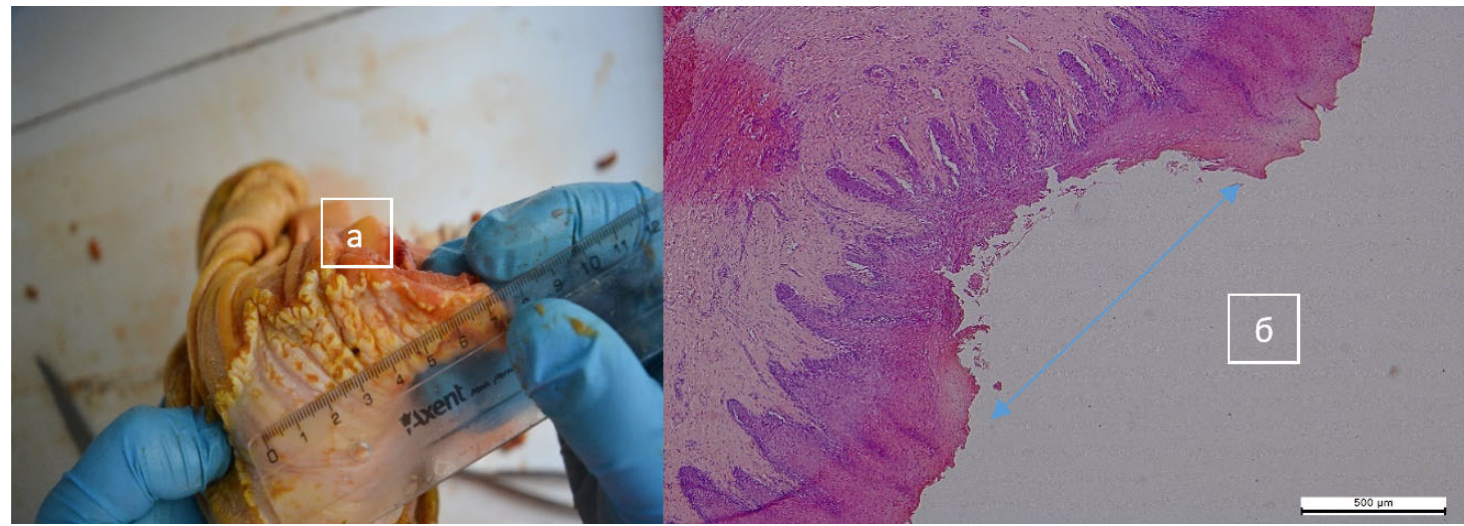

Рис 2. (а) Дрібні, мультифокальні ураження ерозивного характеру поряд з межею margo plicatus

(б) Гістологічна картина з місця ерозії, характеризується ураженням слизового шару без проникнення в глибші шари, $\mathrm{Bar}=500 \mu \mathrm{m}$

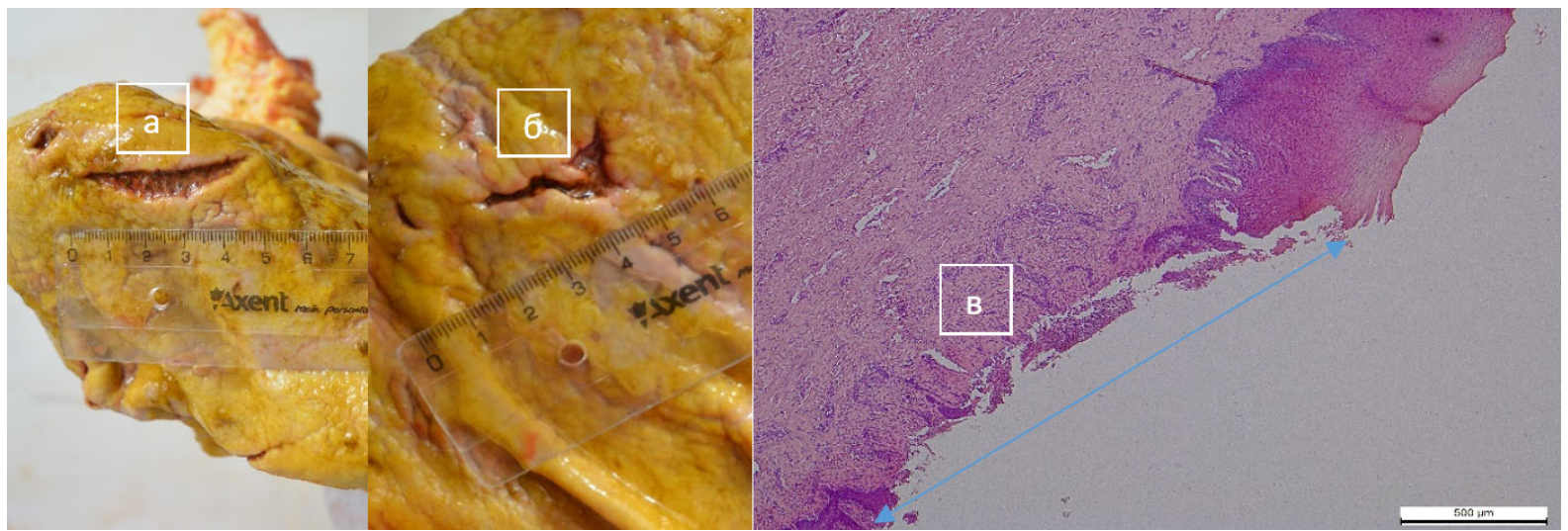

Рис 3. (а, б) Глибокі, проникні виразки, в ділянках кардіальної частини та великої кривизни на незалозистій слизовій оболонці, 4.5 см завширшки (в) Гістологічна картина з місця ульцерації, з ураженням слизового та підслизового шарів, та проникненням в м'язовий шар, $\operatorname{Bar}=500 \mu$

Класифікація уражень в ділянияі залозистої слизової оболонки.

Під час гістологічного дослідження ознаки гіперемії (рис. 4 а). були виявлені в шлунках двох коней на фундальній ділянці у вигляді почервоніння дифуз- ного стінки шлунка. Гістологічна картина вказує на реакцію мікроциркуляторного русла, що в окремих випадках супроводжується десквамацією апікального шару слизової оболонки стінки шлунка (рис. 4 в) та виходом плазми в міжклітинний простір (рис. 4 г). 


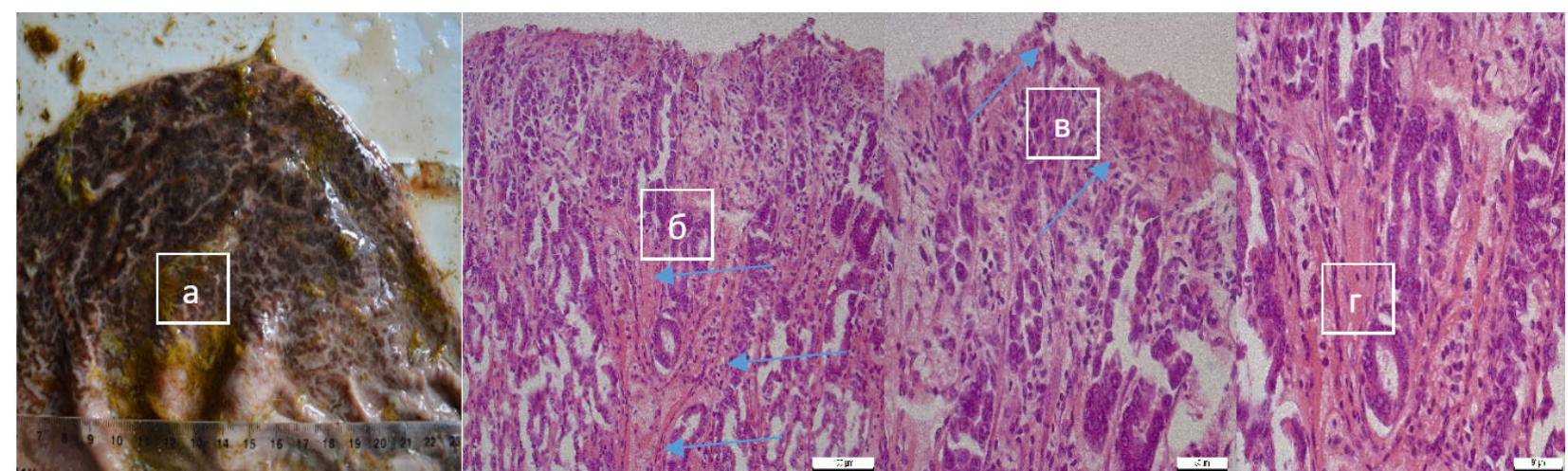

Рис 4. (а) Гіперемія стінок залозистої слизової оболонки шлунка. (б) Гістологічна картина фундальної ділянки шлунка з реакцією мікроциркуляторного русла, капілярів та десквамацією стінки слизового шару Bar $=100 \mu \mathrm{m}$.

(в) $\operatorname{Bar}=50 \mu \mathrm{m}$. (г) Вихід плазми крові в міжклітинний простір, набряк тканин Bar $=50 \mu \mathrm{m}$

Патологічні ділянки на слизових оболонках шлунка були виявлені у шести коней, у чотирьох відсутні. Нами встановлено що ураження незалозистої слизової оболонки $\epsilon$ більш поширеними ніж залозистого відділу шлунка, зокрема у п'яти коней патологічні ділянки були виявлені на межі margo plicatus. Зміни на стінках залозистої слизової оболонки виявлено у фундальному відділі шлунка двох коней. Ураження які локалізувались на слизових оболонках обох відділів шлунка виявлено в одного коня (табл. 4).

\section{Таблиця 4}

Виявлені зміни в ділянках залозистої та незалозистої слизових оболонок шлунка Findings in the squamous and glandular regions of the equine stomach

\begin{tabular}{cccc}
\hline Локалізація & Макроскопічна оцінка & Гістологічна картина & $\begin{array}{c}\text { Кількість коней з } \\
\text { ураженнями }\end{array}$ \\
\hline \multirow{2}{*}{ Кардіальний відділ } & Гіперкератоз & Нашарування зроговілого епітелію & 3 \\
\multirow{2}{*}{ Фундальний відділ } & Локальні ураження & Виразки/ерозї & 2 \\
& Дифузні ураження & Гіперемія & 2 \\
\hline
\end{tabular}

Гіперкератоз, що відповідає 1 ступеню згідно 3 наведеною у роботі системи класифікацї (табл. 2) локалізувався на стінках шлунка трьох коней в межах margo plicatus незалозистої слизової оболонки. Ерозії та виразки, що відповідають більш вираженим змінам 2-3 ступеня локалізувались на стінках незалозистої слизової оболонки двох коней. Місця ураження на фундальному відділі шлунка характеризувались у вигляді гіперемії у двох коней. Аналізуючи відібрані зразки на незалозистій слизовій оболонці шлунка класифікували зміни 2 та 3 ступенів 3 пошкодженнями м'язового, слизового та підслизового шарів (табл. 5). Ознаки нашарування зроговілого епітелію були гістологічно підтверджені на стінках шлунків трьох коней

\section{Таблиця 5}

Дані ступеневих систем класифікації

\begin{tabular}{|c|c|c|c|c|}
\hline Кількість коней & Незалозистій відділ & Залозистий відділ & HSS & MCalister \\
\hline 1 & + & - & 1 & 1 \\
\hline 2 & - & - & 0 & 0 \\
\hline 3 & + & + & 1 & 1 \\
\hline 4 & + & - & 1 & 1 \\
\hline 5 & + & - & 1 & 1 \\
\hline 6 & - & + & 1 & 1 \\
\hline 7 & + & - & 1 & 2 \\
\hline 8 & + & - & 3 & 3 \\
\hline 9 & - & - & 0 & 0 \\
\hline 10 & - & - & 0 & 0 \\
\hline
\end{tabular}

Аналізуючи отримані дані, нами встановлено, що поширеність виразок на слизових оболонках шлунка складає 60\%. Основним місцем локалізації змін на стінках шлунка є ділянка margo plicatus ці дані узгоджуються (Hammond et al., 1986). Отримані дані за- рубіжних публікацій (Fox, 2002; Contreras et al., 2007; Morales et al., 2010) вказують, що в деяких коней 3 ушкодженнями слизових оболонок шлунка, ідентифікували Helicobacter equorum як можливий етіологічний фактор у патогенезі виразок залозистої 
слизової оболонки шлунка коней. В нашій роботі 3 відібраних зразків не вдалось індентифікувати даний мікроорганізм. Також не було виявлено гастрофілів чи інших паразитів. Отже, за даними систем класифікацій нами був встановлений діагноз синдром виразки шлунка коней “EGUS” обох відділів шлунка та різними ступенями ураженнями.

Беручи до уваги поширеність даної патології, використання систем класифікації за синдрому виразки шлунка в коней набуло широкого використання для диференціації, класифікації та опису даної патології. Для детального опису порівняльні дані двох систем $є$ рекомендовані та доповнюючі. Застосування їх у практиці матиме ефективність для визначення лікування та його тривалості при даній патології.

\section{Висновки}

“EGUS” було діагностовано на стінках слизових оболонок шести коней, що вказує на поширеність даної патології у різних порід. Макроскопічна оцінка слизових оболонок та гістологічне дослідження відібраних зразків з місць ураження стінок оцінювались згідно ступеневих систем класифікації. Отримані результати вказують на різні ступені ураження стінок шлунка згідно даних систем, що дозволяють диференціювати тяжкість та характер даної хвороби у коней. За результатами проведення патоморфологічного доіслдіження стану стінки слизової оболонки шлунка та гістологічних змін встановлено ефективність поданих систем класифікації.

\section{References}

Andrews, F.M., Bernard, W., Byars, D., et al. (1999). Recommendations for the diagnosis and treatment of equine gastric ulcer syndrome (EGUS). Equine. Vet. Educ., 11(5), 262-272. https://irpcdn.multiscreensite.com/d048e3f1/files/uploaded/u-

Recommenda-

tions $\% 20$ for $\% 20$ the $\% 20$ diagnosis $\% 20$ and $\% 20$ treatme nt $\% 20$ of $\% 20$ equine $\% 20$ gastric $\% 20$ ulcer $\% 20$ syndrom e.pdf.

Andrews, F.M., Reinemeyer, C.R., Mccracken, M.D., Blackford, J.T., Nadeau, J.A., Saabye, L., Sottel, M., \& Saxton, A. (2002). Comparison of endoscopic, necropsy and histology scoring of equine gastric ulcers. Equine Vet J., 34(5), 475-478. doi: $10.2746 / 042516402776117827$.

Bell, R.J.W., Mogg, T.D. \& Kingston, J.K. (2007). Equine gastric ulcer syndrome in adult horses: A review. New Zealand veterinary journal, 55(1), 1-12. doi: 10.1080/00480169.2007.36728.

Buchanan, B.R., \& Andrews, F.M. (2003). Treatment and prevention of equine gastric ulcer syndrome. Vet Clin North Am Equine Pract, 19(3), 575-597 doi: 10.1016/j.cveq.2003.08.012.
Camacho-Luna, P., Buchanan, B., \& Andrews, F.M. (2018). Advances in Diagnostics and Treatments in Horses and Foals with Gastric and Duodenal Ulcers. Vet Clin North Am Equine Pract, 34(1), 97-111. doi: 10.1016/j.cveq.2017.11.007.

Contreras, M., Morales, A., García-Amado, M.A., De Vera, M., Bermúdez, V., \& Gueneau, P. (2007). Detection of Helicobacter-like DNA in the gastric mucosa of Thoroughbred horses. Lett Appl Microbiol., 45(5), 553-557. doi: $10.1111 / \mathrm{j} .1472-$ 765X.2007.02227.x.

Fox, J.G. (2002). The non-H. pylori helicobacters: their expanding role in gastrointestinal and systemic diseases. Gut., 50(2), 273-283. doi: 10.1136/gut.50.2.273.

Hammond, C.J., Mason, D.K., \& Watkins, K.L. (1986). Gastric ulceration in mature thoroughbred horses. Equine vet. J., 18(4), 284-287. doi: 10.1111/j.20423306.1986.tb03629.x.

Johnson, B., Carlson, G.P., Vatistas, N., Snyder, J.R., Lloyd, K.L. \& Koobs, J. (1994). Investigation of the number and location of gastric ulceration in horses in race training submitted to the California racehorse post-mortem program. Proc. Am. Ass. equine Practnrs, 40, 123-124.

MacAllister, C.G., Andrews, F.M., Deegan, E., et al. (1997). A scoring system for gastric ulcers in the horse. Equine Vet J., 29(6), 430-433. doi: 10.1111/j.2042-3306.1997.tb03154.

Martineau, H., Thompson, H., \& Taylor, D. (2009). Pathology of gastritis and gastric ulceration in the horse. Part 1: Range of lesions present in 21 mature individuals. Equine vet. J., 41(7), 638-644. doi: 10.2746/042516409x464816.

Morales, A., Garcia, F., \& Bermudez, V. (2010) Detection of Helicobacter-like organisms in Thoroughbred horses from, Venezuela. Braz. J. Vet. Path., 3(1), 52-55. https://pdfs.semanticscholar.org/5bfc/010fe938da7fb6 819f27fe7a39e622e6f8a9.pdf.

Murray, M.J., Eichorn, E.S., \& Jeffrey, S.C. (2001) Histological characteristics of induced acute peptic injury in equine gastric squamous epithelium. Equine vet. J., 33(6), 554-560. doi: 10.2746/042516401776563517.

Stefanyk, O., \& Slivinska, L. (2018) Equine gastric ulcer syndrome (EGUS). Prevalence, etiology, diagnostic. Scientific Messenger of LNU of Veterinary Medicine and Biotechnologies. Series: Veterinary Sciences, 20(83), 156-161 doi: 10.15421/nvlvet8330.

Sykes, B.W., Hewetson, M., Hepburn, R.J., Luthersson, N., \& Tamzali, Y. (2015). Equine Gastric Ulcer Syndrome in Adult Horses. ECEIM Consensus Statement. J. Vet. Intern. Med., 29(5), 1288-1299. doi: 10.1111/jvim.13578.

Ward, S., Sykes B.W., Brown, H. et al. (2015) A comparison of the prevalence of gastric ulceration in feral and domesticated horses in the UK. Equine Vet Educ, 27(12), 655-657. doi: 10.1111/eve.12491. 